\title{
The Fruit of Seated (Melastomamalabathricum L.) As Agent for Detecting the Age and Acidity of Dental Plaque
}

\author{
$1^{\text {st }}$ Marlindayanti \\ Dental Nursing \\ Poltekkes Kemenkes Palembang \\ Palembang, Indonesia \\ marlindayanti@gmail.com
}

\author{
$2^{\text {nd }}$ Nur Adiba Hanum \\ Dental Nursing \\ Poltekkes Kemenkes Palembang \\ Palembang, Indonesia \\ nuradibahanum@poltekkespalembang.ac.id
}

\begin{abstract}
Background: Research and Development Agency Ministry of Health, stated that the biggest dental and oral disease in Indonesia is dental caries or dental cavities, with the main cause is dental plaque. Plaque formation begins with the formation of a pellicle immediately after brushing teeth, then experiences interactions with bacteria to form a strong bond with the tooth surface (colonization) and the formation of biofilms. Plaque cannot be seen with the eyes so we need a tool or material that is able to detect it. Senduduk fruit (Melastomamalabathricum $L$ ) is a plant that has the potential to produce anthocyanin pigment sources. The color stability of anthocyanin compounds is influenced by pH or acidity, and will be more stable when in an acidic or low pH.

Method: This study was an experimental study with a pre and post test design. In this study, sampel size was counted by Federer formula, selected through non probability sampling with a purposive sampling technique. Data were analyzed using independent $T$ tests. Results:Sendudk fruit paste can distinguish the age of dental plaque (immature plaque 4 hours with pink or pink, young plaque at 8 hours red, old plaque at 12 hours purple). pH measurements from color of the plaques that arise from red orange, purple to yellowish blue (yellowish blue, purple indicate alkaline $\mathrm{pH}$ and orange red acidic pH). Conclusion:Senduduk fruit paste can be used as aagent for detecting the age and acidity of dental plaque.
\end{abstract}

Keywords: Senduduk fruit, dental plaque

\section{INTRODUCTION}

Basic Health Research (RISKESDAS) in 2018 stated that $57.6 \%$ of Indonesian people experience oral and dental problems. The main cause of dental and mouth disease is plaque. Plaque is a major problem in the oral cavity, which can cause inflammation of the soft tissues such as gingivitis and can damage hard tissues such as cavities. Plaque consists of microorganisms that multiply in the intercellular matrix in the form of bacteria and bacterial products. Plaque is also able to change food scraps (leftovers) food [1]. The soft, white, sticky mass makes dental plaque only to be removed by brushing.

Thin plaque is almost the same color as the teeth, so the plaque cannot be seen with the eye unless the plaque is stained with dye. A coloring agent is a revealing solution. Disclosure solutions work Change the color of the dental plaque so that it contrasts with the surface color of the white teeth [2]. Natural dye indicators use substances that have dyes that are generally derived from plants such as roots, leaves, flowers, fruit, and seeds. This plant can be made through additional solvent extraction [3]. The use of herbal medicine as an indicator of natural dyes for acidbase titrations containing anthocyanin color pigments that can change color at any specific $\mathrm{pH}$ change [4]. Almost all plants that produce color can be used as indicators of natural dyes whose color changes are less pronounced or almost similar to certain $\mathrm{pH}$ changes.

Some research has been done about natural dyes for the detection of plaque i.e. red Dragon fruit as natural dye substitute disclosing solution and tuber beet extract (Beta vulgaris L) as dye material plaque. One of the plants containing the color of anthocyanin compounds that are derived from the flavonoids group is the fruit of the seated [5]. The fruit of the seated (Melastomamalabathricumshot L) is a plant that grows in Indonesia, regarded as a potentially wild plant in 
producing anthocyanin pigment sources. The fruit can be classified as a fruit that chaps in several parts, in dark purple, sweet taste a little bitter and has orange seeds. The fruit is edible and when eaten, it will leave the color of purple to the blue tooth [6]. The sensit contains compound flavonoids, saponins, tannins, glycosides, Steroids/triterpenoids. The active substance that is contained in the sitting leaves acting as a wound healer is: flavonoids serve as anti-inflammatory, antiallergic, antioxidant. The Steroid serves as an antiinflammatory.

\section{METHOD}

The type of research used in this research is experimentation with pre and post-test design to find out if the fruit extract (Melastomamalabathricm L.) can be used as a bacterial colonization inhibitor paste. Research in August and Oktober2019 in several places, namely: the manufacture of extracts in the Laboratory of STIFI, the Clinical calculation of bacteria in BBLK Palembang, and measurement of plaque (age and $\mathrm{pH}$ ) at Pondok PesantrenLunjuk Jaya. The subject of research selected through nonprobability sampling with the technique of sampling purposive with the criteria of inclusion as follows: Children boarding school living in boarding schools Alamalul Khoir Palembang with the same diet, age 1415 years, Not use orthodontic, can be invited to communicate and fill informed consent. While the exclusivity criteria are: general and oral health conditions are not good when conducted research, respondents refused participation in the research (uncooperative), absent when the research was conducted. Samples were taken using the Ferderer's formula and obtained a minimum amount of samples $>$ 4 , and in this study used a sample of 10 people each group and a total sample of 60 people (30 control groups and 30 treatment groups).

The first $\mathrm{pH}$ of plaque is calculated using the $\mathrm{pH}$ paper after the treatment is given the act of the dripping fruit paste (Melastomamalabathricumshot L) and a past disclosing Solution (Tri Plaque Gel). Then to detect the age of plaque, researchers instruct the research samples to perform the toothbrush so that the $\mathrm{pH}$ plaque becomes 0 and will be calculated the age of plaque with time- based treatment which is 4 hours, 8 hours, and 12 hours. In the calculation of the age of sample plaque research is conditioned in a state of fasting or not consume anything with that time, after that the sample is given the treatment with a shed fruit paste (Melastomamalabathricumshot L) and pasta Disclosing solution (Tri Plaque Gel).

\section{RESULTS}

A seated fruit paste (Melastomamalabathricumshot L) can distinguish the degree of acidity $(\mathrm{pH})$ arising. Judging by the color of the fruit paste (Melastomamalabathricumshot L) More than the paste Tri Plaque Geek. The color degradable in the plaque is observed using a $\mathrm{pH}$ paper so that it can also be determined the $\mathrm{pH}$ plaque score (Diagram 1).

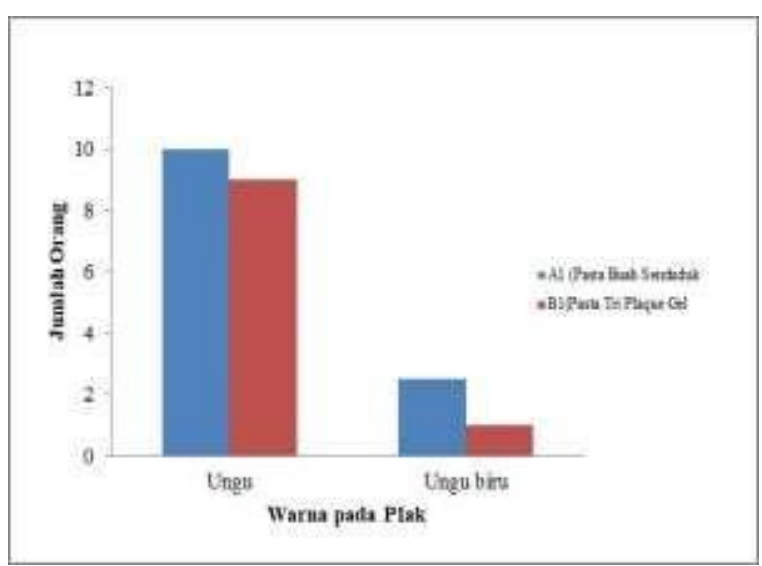

Diagram 1.pH plaque is reviewed from the color degradation of plaque due to treatment using the seated fruit (Melastomamalabathricumshot L) and disclosing solution (Tri Plaque Gel). In the treatment group, there is a single color that has been inflicted with a seated fruit extract, the Age of plaque (4 hours) in Pink/red, whereas the Paste Tri plaque Gel produces two colors namely Pink/red and Red (Diagram 2).

Diagram 2. Detection of plaque age after tooth brushing within 4 hours in the treatment of the seated fruit (Melastomamalabathricumshot L) and disclosing solution (Tri Plaque Gel)

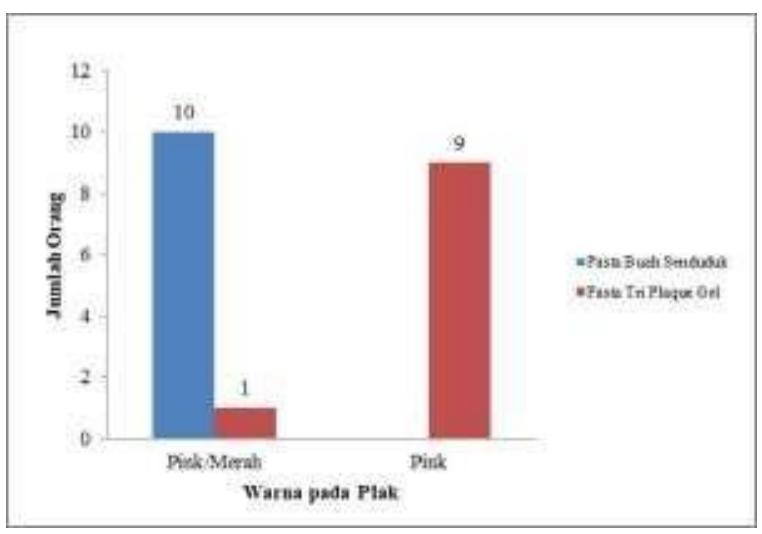

The aging treatment of 8 hours plaque, a visible paste of fruit extract of the seated produce 3 colors ranging 
from purplish red, purple, and bright red, while triplaque gel only appears two colors namely purplish and purple-red only (Diagram 3).

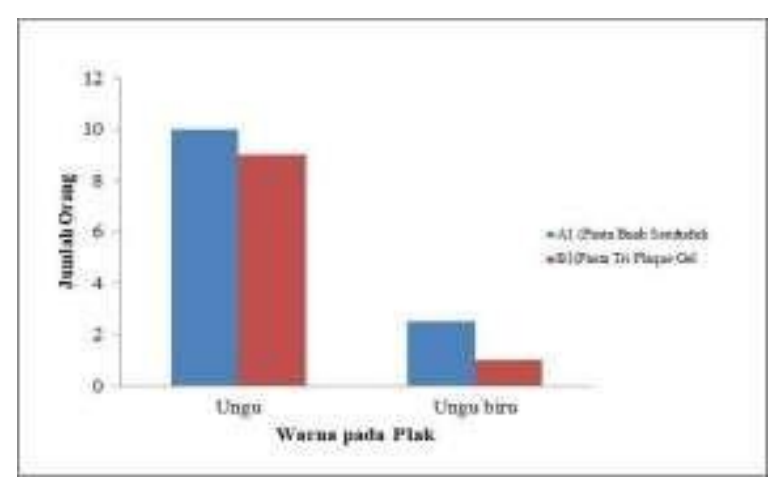

Diagram 3. Detection of plaque age after tooth brushing within 8 hours in the treatment of the seated fruit (Melastomamalabathricumshot L) and disclosing solution (Tri Plaque Gel)

The aging treatment of 12 hours plaque both materials show the coloring that arises the same that is purple and purple bluish (Diagram 4).

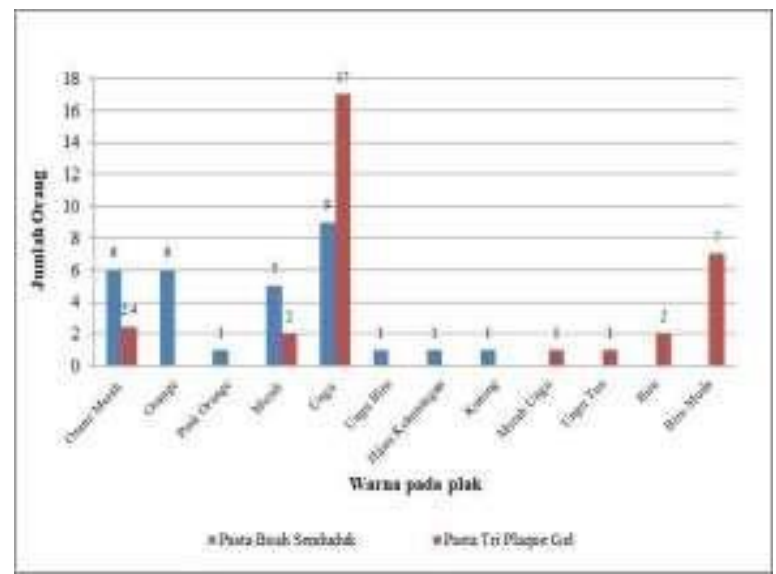

Diagram 4. Detection of plaque age after tooth brushing within 12 hours in the treatment of the seated fruit (Melastomamalabathricumshot $\mathrm{L}$ ) and disclosing solution (Tri Plaque Gel) With analysis using Test T Independent to color degradation and age of plaque on the treatment of 4,8 and 12 hours known respectively p-value 4 hours $=0305,8$ hours $=0329$, and 12 hours $=0305$ with a significance value of $>$ of 0.05 then it means a seated fruit (Melastomamalabathricumshot L) no different (same) with disclosing solution (Tri Plaque Gel) in the function of plaque detection and acid detection.
Table 1. Statistical Test $\mathrm{T}$ independent degradation of color and $\mathrm{pH}$ plaque at 4 hours and 8 hours treatment

\begin{tabular}{|c|c|c|c|c|c|c|c|}
\hline \multicolumn{8}{|c|}{ Levene's Test for Equality of variances } \\
\hline & & $\mathrm{F}$ & Sig & $\mathrm{t}$ & df & $\begin{array}{l}\text { Sig (2 } \\
\text { tailed) }\end{array}$ & $\begin{array}{l}\text { Mean } \\
\text { Differen } \\
\text { ce }\end{array}$ \\
\hline \multirow[t]{2}{*}{ Hasil } & $\begin{array}{l}\text { Equal } \\
\text { variances } \\
\text { assumed }\end{array}$ & 4.457 & 0.041 & 1.000 & 38.00 & 0.324 & 0.0500 \\
\hline & $\begin{array}{l}\text { Equal } \\
\text { variances } \\
\text { not } \\
\text { assumed }\end{array}$ & & & 1.000 & 19.00 & 0.330 & 0,0500 \\
\hline
\end{tabular}

Table 2. Statistical test T Independent color degradation and $\mathrm{pH}$ plaque at 4 hours and 12 hours treatment

\begin{tabular}{|c|c|c|c|c|c|c|c|}
\hline \multicolumn{8}{|c|}{ Levene's Test for Equality_of Variances } \\
\hline & & $\mathrm{F}$ & Sig. & $\mathrm{t}$ & df & $\begin{array}{l}\text { Sig. (2- } \\
\text { tailed) }\end{array}$ & $\begin{array}{c}\text { Mean } \\
\text { Differen } \\
\text { ce }\end{array}$ \\
\hline \multirow[t]{2}{*}{ Hasil } & $\begin{array}{l}\text { Equal } \\
\text { varianc } \\
\text { es } \\
\text { assumed }\end{array}$ & 4.457 & .041 & -19.00 & 38 & 0.000 & -.95000 \\
\hline & $\begin{array}{l}\text { Equal } \\
\text { varianc } \\
\text { es not } \\
\text { assumed }\end{array}$ & & & -19.00 & 19.00 & 0.000 & -.95000 \\
\hline
\end{tabular}

Table 3. Statistical test T Independent color degradation and $\mathrm{pH}$ plaque at 8 hours and 12 hours treatment

\begin{tabular}{|c|c|c|c|c|c|c|c|}
\hline \multicolumn{8}{|c|}{ Levene's Test for Equality of Variances } \\
\hline & & & Sig & $\mathrm{t}$ & df & $\begin{array}{l}\operatorname{sig}(2 \\
\text { tailed }\end{array}$ & $\begin{array}{c}\text { Mean } \\
\text { Difference }\end{array}$ \\
\hline \multirow[t]{2}{*}{ Hasil } & $\begin{array}{l}\text { Equal } \\
\text { variances } \\
\text { assumed }\end{array}$ & 4.457 & .041 & -19.00 & 38 & 0.000 & -.95000 \\
\hline & $\begin{array}{l}\text { Equal } \\
\text { variances } \\
\text { not } \\
\text { assumed }\end{array}$ & & & -19.00 & 19 & 0,000 & -.95000 \\
\hline
\end{tabular}

\section{DISCUSSION}

Tooth plaque staining is the most important thing in the dentistry world as a tool to detect the age of plaque. The material used to detect plaque is dye synthesis and natural dyes. Synthetic dyes that are often used are disclosing solutions for example Tri plaque gel. This dye is used as an ingredient for measuring and calculating the hygiene of the teeth and mouth, seeing the success of brushing teeth. Cake dyes can also be used but have a deficiency that can not last long and quickly fade when mixed with saliva, while the disclosing solution is able to change color according to 
the age of dental plaque and survive long enough. Hypotheses that declare a seated fruit (Melastomamalabathricumshot L) can be used as an alternative to plaque detection.

Natural dyes containing the color of anthocyanin compounds that are derived from the flavonoids group is the fruit of the seated. The fruit of the seated (Melastomamalabathricumshot L) is a potential plant in producing anthocyanin pigment sources (staining). The color of the anthocyanin pigment produced from the Seated fruit (Melastomamalabacthicum L) varies in its concentration [5]. Color degradation in the staining of plaque caused by the fruit of the seated (Melastomamalabacthicum L) is if the plaque is getting older the color will be increasingly concentrated that starts from the color of the young or low (pink/red), Medium (purple) to a dense color (blue). The treatment produces a very low concentration of pink/red (signifying a new plaque) in the treatment of 4 to 8 hours after brushing the tooth, while the treatment resulting in purple color with moderate opacity (indicating young plaque) was obtained at 8 to 24 hours after brushing the tooth. If the plaque age is already more than 24 hours the color of the plaque will be increasingly concentrated with the blue color (old plaque).

This research is in line with A Geraldine stating that the color will be increasingly concentrated if the old plaque becomes. The excess fruit of the other natural dyes is the color that is generated from the light to the thick color that can cause from the color of pink to purple color. While the color posed by other dyes is only concentrated without changing the color.

Discoloration indicating the degree of acidity of plaque in this study is that in the acidic atmosphere, the anthocyanin pigment in the dark fruit is pink/red, base atmosphere colored purple or blue. This research shows that the fruit paste can see a drastic color change, discoloration from pink to purple indicating that the base acid $\mathrm{pH}$ can be seen from the color of the arising. The $\mathrm{pH}$ of color acid that arises bright while the $\mathrm{pH}$ base of the color that arises concentrated (7). said that the color stability of anthocyanin fruit compounds is influenced by $\mathrm{pH}$ or acidity, and will be stable when in an acidic or low $\mathrm{pH}$ setting. The color arising from the $\mathrm{pH}$ of anthocyanin acid fruit is redorange while in the $\mathrm{pH}$ base anthocyanin blue-purple or sometimes yellow.

To distinguish the degree of acidity of the sample plaque we also test using a $\mathrm{pH}$ paper. To test the acidbase plaque by measuring the $\mathrm{pH}$ saliva can use a $\mathrm{pH}$ paper (Web FKG.ui.ac.id) In addition we also tested the degree of acidity $(\mathrm{pH})$ in a person who has calculus by giving the fruit a seated (Melastomamalabathricumshot L) and see the discoloration of the resulting, purple color shown indicates alkaline $\mathrm{pH}$. The research is also in line with Research Anph acid bases on bits of fruit, where the results state that bits of fruit are able to tell the $\mathrm{pH}$ of plaque. But different from this research because the fruit research has been able to determine the $\mathrm{pH}$ of acid bases by way of viewing colors while researching the bits of fruit in determining the $\mathrm{pH}$ of acid bases by means of using the OHIS scoring.

\section{CONCLUSIONS}

Based on the results of the research on fruit paste (Melastomamalabathricumshot L) can be used as an alternative to the detection of plaque by means of 3 drops of hatchling under the tongue and flattened throughout the tooth surface at treatment 4,8 and 24 hours after brushing teeth can be concluded:

1. Fruit paste (MelastomaMalabathrifondl) can distinguish the age of plaque, the color degradation caused by the fruit of the seated (MelastomaMalabathrifondl) ranging from pink/red, purple to blue.

2. A seated fruit paste can detect the degree of acidity $(\mathrm{pH})$, with pink/red in the acidic atmosphere and purple color in an alkaline atmosphere.

3. The fruit paste (MelastomaMalabathrifondl) serves as a plaque detection and acid detection.

With the conclusion above the author tried to give the advice to improve the health of teeth and mouth, namely the need to do further research on fruit paste (Melastomamalabathricumshot L) as a material dye plaque and can be developed into a business.

\section{REFERENCES}

[1] Penda PAC, Kaligis SHM, . J. Perbedaan Indeks Plak Sebelum Dan Sesudah Pengunyahan Buah Apel. E-GIGI 2015;3. https://doi.org/10.35790/eg.3.2.2015.9631.

[2] Fatmawati DWA. Hubungan Biofil Streptococcus Mutans Terhadap Resiko Terjadinya Karies Gigi. Hub Biofil Streptococcus Mutans Terhadap Resiko Terjadinya Karies Gigi 2016;8:127-30.

[3] Che Omar SN, Ong Abdullah J, Khairoji KA, Chin Chin S, Hamid M. Effects of flower and fruit extracts of Melastoma malabathricum Linn. on growth of pathogenic bacteria: Listeria monocytogenes, Staphylococcus aureus, Escherichia coli, and salmonella typhimurium. Evidence-Based Complement Altern Med 2013;2013. 
https://doi.org/10.1155/2013/459089.

[4] Singh LK, Karlo T, Pandey A. Performance of fruit extract of Melastoma malabathricum L. as sensitizer in DSSCs. Spectrochim Acta - Part A Mol Biomol Spectrosc 2014;118:938-43. https://doi.org/10.1016/j.saa.2013.09.075.

[5] Alnajar ZAA, Abdulla MA, Ali HM, Alshawsh MA, Hadi AHA. Acute toxicity evaluation, antibacterial, antioxidant and immunomodulatory effects of Melastoma malabathricum. Molecules 2012;17:3547-59. https://doi.org/10.3390/molecules 17033547.

[6] Melianti. Isolasi zat warna (antosianin) alami dari buah senduduk akar (Melastoma malabathricum 1.) dengan metode ekstraksi maserasi menggunakan pelarut etanol. Distilasi 2018;3:8-15.

[7] Joffry SM, Yob NJ, Rofiee MS, Affandi MMRMM, Suhaili Z, Othman F, et al. Melastoma malabathricum (L.) smith ethnomedicinal uses, chemical constituents, and pharmacological properties: A review. Evidence-Based Complement Altern Med 2012;2012. https://doi.org/10.1155/2012/258434.

[8] Anuar N, Mohd Adnan AF, Saat N, Aziz N, Mat Taha R. Optimization of extraction parameters by using response surface methodology, purification, and identification of anthocyanin pigments in melastoma malabathricum fruit. Sci World J 2013;2013. https://doi.org/10.1155/2013/810547. 